International Journal of Business Management, Entrepreneurship and Innovation, Volume 3, Issue 2, 2021, PP 72-89, ISSN 2707-8027

IBMED

\title{
Organization Social Practice and Performance in the Kenya National Police Service: A Case of Central Police Division, Nairobi, Kenya
}

\author{
Isack Tenai ${ }^{1}$, Philip Wambua ${ }^{2}$ \\ ${ }^{1}$ Student, Master of Business Administration (Strategic Management Option), School of Business, \\ Kenyatta University, Kenya \\ ${ }^{2}$ Department of Business Administration, School of Business, Kenyatta University, Kenya
}

ABSTRACT

The National Police Service of Kenya has gone through numerous transformations which are aimed at making it more effective and socially aligned to the needs of the Kenyan population. The transformation has seen the renaming of the policing unit from Kenyan Police Force to its current name. The Strategy such as renaming the institution to National Police Service implies that the institution is improving its commitment to improve service delivery to the citizens in a favorable social framework. However, minimal studies have been done to determine the existence of any relationship between organizational social practices and performance of the police institution. Therefore, the current study was formulated to establish the influence of organizational social practices on the performances of the National Police Service. The independent variables of the study included leadership style, organization structure, professionalism, and organization politics. Practice and system theories were reviewed alongside relevant sources of empirical literatures were reviewed to give the current studies sound theoretical and empirical foundations. Descriptive research design was used to guide collection, analysis, and interpretation of the research data. Semi-structured questionnaires were used to collect quantitative and qualitative data was collected from 150 police officers who were purposively sampled from Central Police Division in Nairobi County. A combination of descriptive and inferential analyses were performed to establish the current trends of the study variables and relationships thereof. The study found out that the respondents were in agreement with almost statements on the four organizational social practices including leadership style, organization structure, and professionalism and organization politics. Leadership style and professionalism were established to have the highest impact $(0.300 ; p=$ $0.000)$ and the least impact $(0.093 ; p=0.000)$ respectively. Organization politics, on the other hand had a significant negative impact $(-0.254 ; p=0.001)$ on the NPS performance. The study concludes that the main belief or attitude influencing leadership style is the perceived manager versus subordinates' role. Effective decision making is improved by decentralization, narrow control span and efficiency relate positively, task routine positively and negatively affect productivity. A respectful culture is fostered by professionalism, which ensure proper handling of conflicts. Boundaries are clearly understood and minor issues solve efficiently and respectfully by professional employees. Workers are motivated with the hope that there won't be hampering of their interest due to existence of organizational politics. Employee's indiscipline may be resisted by the organizational politics' help. The study recommends that transactional and transformative leadership be embraced by national police service to assist in tapping the workers' potential, they should be involved in making decisions and new idea be welcomed into the system for positive contribution to the entities' exponential performance. National police service should adopt an efficient, simple and universally accepted organizational structure. Employees at national police service should exercise workplace 
International Journal of Business Management, Entrepreneurship and Innovation, Volume 3, Issue 2, 2021, PP 72-89, ISSN 2707-8027

IBNED

expectations and rules by following all workplace rules, completing all projects and tasks and understanding what is expected of them. Delegation of duties depending on employees' academic achievements, specialization and interests. Transparency must be maintained at all levels to reduce politics.

Key Words: Leadership, Organization Social Practice, Kenya National Police Service

DOI 10.35942/ jbmed.v3i2.194

\section{Cite this Article:}

Tenai, I., \& Wambua, P. (2021). Organization Social Practice and Performance in the Kenya National Police Service: A Case of Central Police Division, Nairobi. International Journal of Business Management, Entrepreneurship and Innovation, 3(2), 72-89. https://doi.org/10.35942/jbmed.v3i2.194

\subsection{Introduction}

The desire to meet dynamic demands of customers has been influencing the choice of management practices in every kind of organizations. Public and private institutions are in the race to adopt different practices to improve their performance and eventual delivery of quality services to their clients (Mohagheghi \& Raji, 2014). Kumbargeri and Sinha (2017) noted that good management practices are those that entail integration of the organization's social aspects such as transformational leadership styles, professionalism, organizational structure, and positive organizational politics. Kumbargeri and Sinha (2017) further note that adoption of these practices are informed by the increasing concern for the workforce's social well-being instead of just looking into their material needs. It is important to note that employees' needs go beyond financial compensation. The complexity of employees' needs is vividly explained in Maslow's hierarchy of needs. It explain that the employees' needs level evolves from the most basic needs such as food and shelter to higher levels of self-actualization, which is a social factor. Therefore, an organization that intend to improve performance of its employees should strive to address its social aspects in its daily operations.

Several institutions, including law enforcement organizations across the globe have moved to integrate social practices in their management. Police department in England is an example in this management move. Before and during the 1700s, policing and law enforcement were not administered nationally but by local communities such as local authorities. Sources indicate that the Parliament of England of 1673 introduced constables and watchmen to patrol town during the night whereas rural areas depended on other informal arrangements (Raijin, 2012; Petrović et al., 2016). By early 1800s, many town authorities had improved in local policing and the 1800 Act of parliament enabled Glasgow to create the City of Glasgow Police department becoming the first professional police force in Europe. As the population increased, more bills were passed to develop better management practices in the police force in order to improve performance. Naem and Welford (2019) indicate that globally, organizational social practice is a key part in the companies' strategies in promoting sustainable development. Various domestic and multinational companies in Pakistan work in various areas. In considering the long term strategy, responsible and ethical behaviour must be adopted by the business. Hameed (2019) indicate that a company's ethical, social and environmental awareness in their strategy must be considered in increasing general awareness about CSR and try going charity or philanthropy and to become ethical corporate 
International Journal of Business Management, Entrepreneurship and Innovation, Volume 3, Issue 2, 2021, PP 72-89, ISSN 2707-8027

IBNED

citizen, adopt a long-term sustainable business strategy. This will result to Pakistan being an attractive place for investors

The dynamic nature of business environment and social expectations of customers have prompted and necessitated the exigency for organizations to be innovative in order to stay competitive while satisfying the needs of their customers (Al-Jarreh \& Asleh, 2016). Fubara (2020) social practices and understanding of the trend in the environment could assist manufacturing firms in rivers state, Nigeria to produce goods and services that meet customers' satisfaction at profit. In addition, Fubara (2020) suggests that top managers should drive innovativeness however; there should be a process and structure that solicits and accommodates the ideas and suggestions of subordinates in the innovativeness initiative.

Wanjiku (2019) observe that organizational social practices stands as an excellent strategy to improve the firm's competitive advantage through the creation of a sound public image of Group 4 Security Company in Kenya and also helps companies to self-regulate when it comes to the management of stakeholder interests. In addition, Wanjiku (2019) suggests that there should be a periodic evaluation of corporate social responsibility strategies at G4S to reduce the problems established for the second objective. There is a need for these employees to be duly involved in these processes because it creates a broader source of ideas, hence a higher likelihood of success. National Police Service is the main law enforcement agency which is responsible for keeping law and in order in Kenya. The agency was formed in the year 2010 through the National Police Service Act of 2011, following the new constitution's promulgation. It is divided into three arms which consist of the directorate of criminal investigations, Kenya police and the administration police service (Njuguna et al., 2015). The three arms are entrusted with overlapping roles of maintaining law and order in different jurisdictions of law enforcement. Kenya police service plays the primary role of ensuring security as well as enforcing the law within the country. Administration police, on the other hand are responsible for ensuring boarder security in addition to preventing banditry among members of the society. Equally important is the Directorate of Criminal investigation which deals with investigations of complex cases.

The institution of National Police Service has metamorphosed over the years since its formation to improve its service delivery to the citizens. Key among the transformations in the institution was the change from the infamous Kenya Police Force to Kenya Police Service through the 2010 constitution promulgation. Hope (2015) noted that key objective of the police's reorientation was to facilitate the institution's improved performance by ensuring police officers' professionalism and cordial relationship with the citizens. The changes in the NPS has majorly concentrated on the social aspects of the officers' lives such as improving their housing, interpersonal relationships, professionalism, and leadership framework (Hope, 2015). For instance, the national police service commission was also established to oversee the work of the national police service and due to public demand they have conducted radical surgery to better its performance. Adoption of organizational social practices is expected to enhance the process of building professional skills among the police officers and favorable work environment for delivery of policing services in a respectful and efficient manner. However, the institution is yet to achieve its desired level of performance as stipulated in the Kenya Police Service Strategic Plans of 2004-2008. The strategic plan stipulates key mandate of the Kenyan Police service to include maintenance of law land order, detecting and preventing crime, apprehending offenders, protecting property and life, and preserving peace in addition to enforcement of all laws and regulations within its jurisdictions. There is a critical need to objectively evaluate how National Police Service's performance is 
International Journal of Business Management, Entrepreneurship and Innovation, Volume 3, Issue 2, 2021, PP 72-89, ISSN 2707-8027

IBNED

effected by the prevailing social practices since the institution's performance is gauged by the level to which its customers, Kenyan citizens, are satisfied with their service delivery (National Police Service Act, 2011).

\subsection{Statement of the Problem}

The need to increase service delivery and better relationship between members of the pubic and Kenya National Police Service has seen the institution undergo several social and organizational restructuring over the years, especially after the 2010 constitution's promulgation. Some of the restructuring involved improving social welfare of the police officers and building trust among members of the public about the police service. Different trainings have been done to the police officers as well as their bosses to transform the management approach within the service. Instead of the rigid running of the police service, stakeholders in the Kenyan security sector have advocated for a socially responsible policing. Improvements such as formation of Independent Police Oversight Authority and partnering with institutions of higher learning like Kenyatta University to train police officers in peace and human resources management are some of the efforts the National Police Service has made to ensure sound organizational structure, good leadership, and professionalism within the institution.

The above trends indicate that the National Police Service has been making serious financial, entrepreneurial, and social investments in its management. However, different reports still reveal substantial level of dissatisfaction among members of the public as far police services are concerned. A good number of Kenyans are yet to be convinced about their security. Police officers are still being cited among perpetrators of criminal activities including extrajudicial killings, corruption, and torture of innocent civilians (Botha \& Abdile, 2020; UNODC, 2011; Waweru \& Maina, 2019). Additionally, reports commissioned by the Kenyan government (Waki report (2008), The Kenya police task force on reforms (2009), John Krigler report (2007) and (Ransely, 2008) all state that the National Police Service has poorly adapted to external environment changes. The implication is that the performance of National Police Service has not met expectations of the public despite the social and financial investments that have made. Therefore, there is need to assess whether any relationships exist between performance of the National Police Service and their organizational social practices.

A study by Nasieku, Togun and Olubunmi (2014) assessed the relationship between oorganizational performance and social practices and revealed a strong association between a firm's social practices and its performance. However, the study used exploratory research design. Martinez-Conesa, Soto-Acosta and Palacios-Manzano (2017). Organizational social practices and how it affects innovation and firm performance, it was disclosed that organizational social practices is a crucial driver for performance of the firm majorly through organizational innovation enhancement. However, the study context was small and medium enterprises. Malik, Ali and Ishfaq (2018) study examined how organizational social practices influenced organizational performance and organizational social practices are sufficient for direct communication with their clients, helping to improve economic productivity. However, the study focused on banking industryry. This project sought to fill this knowledge gap by correlating organization social practices and Kenya National Police Service's performance through its central police division in Nairobi, Kenya. 
International Journal of Business Management, Entrepreneurship and Innovation, Volume 3, Issue 2, 2021, PP 72-89, ISSN 2707-8027

IBMED

\subsection{Objectives of the study}

The general objective of the study was to establish the influence of organizational social practice on performance in the Kenya National Police Service (NPS).

Specific Objectives were to:

i. To determine the influence of leadership style on police performance in Central police division Nairobi, Kenya.

ii. To establish the influence of organizational structure on police performance in Central police division Nairobi, Kenya.

iii. To assess the influence of professionalism on police performance in Central police division Nairobi, Kenya.

iv. To evaluate the influence of organizational politics on police performance in Central police division Nairobi, Kenya.

\subsection{Theoretical Literature Review}

\subsubsection{Theoretical Literature}

\subsubsection{Contingency Theory}

Burns and Stulker (1961) propounded it. He emphasized the need of examining situations or contingencies' role in an institution and its behaviour. Lawrence \& Lorsh (2009) posit that according to it, firms must be differentiated and integrated to a level of contingent, optimality upon environmental uncertainty level. The theory's essence is that best practices are dependent on the situation's contingencies, hence aids in analyzing situations and determining the variables influencing strategic decisions. It claims that if organizational structure is matched to contingencies, organizational effectiveness is attained. This theory presupposes those various solutions prove very effective under various circumstances (Ongeti, 2014). This is regarded among the theory's key insights since this theory asserts that different organizational strategies and structures are required for different circumstances instead of universally prescribing applicable organization management practices. Thus, match between the organizational structure and a strategy is determines corporate strategy' successful implementation. strategic alignment's role enhancing the match between an institution's environment and organizational strategic priorities leading to organizational execution support is underscored by the contingency theory (Morton and $\mathrm{Hu}, 2015)$.

\subsubsection{Practice Theory}

Practice theory is driven from Aristotle's phronesis concept which describes practical wisdom which is intended to generate praxis, an act which is brought about by knowledgeable value-driven discussions. Phronesis is a Greek term for a means knowing which results into practical form of knowledge or wisdom termed as praxis. Nicolini (2012) emphasizes that praxis is an act of doing things with single objective of doing them well, in the moral and political sense as denoted by Aristotle's enpraxia. In his sixth book, Aristotle defined practical wisdom as a characteristic of a mind that is concerned with noble and just things which are also good for mankind. Such a mind is focused on human and nonhuman entities about concrete deliberations can be done. He added that anyone with practical wisdom engages in productive deliberations to achieve practical ends (Nicolini, 2012). Aristotle's thoughts on this subject can then be summarized by describing phronesis/praxis as a state of mind or an intellectual virtue that is concerned with value-driven 
International Journal of Business Management, Entrepreneurship and Innovation, Volume 3, Issue 2, 2021, PP 72-89, ISSN 2707-8027

IBMED

deliberations and ethical actions contextualized in human affairs, especially in the management of organizations. Praxis is a flexible form of knowledge that is teachable and permits members of an organization to pursue happiness in fulfilling their daily activities within and outside their organization (Garcia \& Acosta, 2020).

The concept was developed into praxeology or the practice theory by Pierre Bourdieu. The sociologist argued that social agents such as members of an organization develop strategies which are adapted to the structures of their social institutions in which they reside. The theory was developed through the habitus concept whose tenets was that the strategies of social agents are often unconscious and are manifested at the level of bodily logic. The implication of praxeology is that the operations of any autonomous field such as politics, education, business, or an economy is ultimately determined by the social relations. Such relations are built by the social agents as they engage in their daily practices (Welch \& Yates, 2018). The daily practices disposes the social agents to social actions. It is through the dispositions that individuals acquire lasting values for the organizational performance.

Therefore, practice theory advocates that an organization is a progressive entity where active men develop their ideological reflexes and material productivity in a communal interactivity. This theory explains the interdependence of organizational performance on the routine social practices and structures of an organization. Organizational performance stands out as the ultimate end of practical activity, achieved through a practical process of developing members of an organization's workforce. The development can be facilitated through favorable leadership style as practiced in an enabling organizational structure. The values such as professionalism then becomes a necessary means of serving humanity as a moral obligation. In addition to being actors and producers, men including members of an organization are thinking beings. Therefore, their ability to perform is also influenced by the kinds of thoughts and perception they hold about the organization, their peers, and even their work. The thoughts and perceptions often manifest in how they relate and speak about affairs of the organization. Such perceptions and internal relationship among members of an organization are collectively termed as organizational politics.

\subsubsection{System Theory}

It was propagated by Ludwig Von Bertanlanffy in 1956. The theory holds that a firm's environment has a strong influence on its makeup and operations (Harvey, 2005). While referring to an organization as a system, the theory defined a system as multiple parts combination working interdependently to produce a unified outcome. An organization is considered as an organic and a social system that operates in complex internal and external environments. The internal environment includes its internal structures, procedures, and the human resources. The external environment includes other stakeholders such as the government agencies, members of the public, and suppliers among others. Advocates of the open systems theory argue that organizational performance is influenced by the prevailing factors in the internal and external environment. Therefore, better performance can be achieved through a synergized operations of every segment of the organization through a functional organization structure and sound leadership. In the case of service organizations such as the National Police Service, the structure and leadership should be focused on instilling moral values such as professionalism and fairness among the police officers because they are primary agents of service delivery.

The theory points out that the prevailing changes in the external and internal environments are often created and influenced by the daily interactions and conduct of businesses among 
International Journal of Business Management, Entrepreneurship and Innovation, Volume 3, Issue 2, 2021, PP 72-89, ISSN 2707-8027

\section{IBMED}

communities and organizations. Pfeffer and Salancik (2003) observed that organizations and communities are equally affected by external changes in global and local environments through an active adaptive change which is a two-way influential change. The scholars proposed that the environment is made up of other organizations with the tendency to exert diverse social, political, or economic forces. The organizations are also sustained by key resources provided by the environment for their transformation and survival. Thus, communities and organizations are systems which are open to change and influence one another over time. The flow of information, energy, and materials is also important within the system boundaries to separate the system from the external environment.

According to Pfeffer and Salancik (2003), there is need for an active and open adaptive relationship between a system and its external environment for it to be viable. There should be a direct correlation between a healthy viable open system and its external environment as far as changing expectations and values over time are concerned. Therefore, a community or an organization is likely to become unviable or unhealthy in case their expectations and values are not in sync with the expectations and values existing in the external environment. Pfeffer and Salancik (2003) also noted that people can also be classified as open systems since they affect and are also affected by their external environment. For instance, an individual's actions are bound to influence and even change his or her external environment. Similarly, individuals experience constant influence from their external environment which often leads to some changes. Organizations are often considered by their employees as an immediate external environment capable of influencing and changing their social, political, and even economic perspectives. The concept of organizational open system is even magnified in the unique provision of police services. The success of police institutions greatly depends on the joint social skills and social wellbeing of the police officers in addition to the prevailing attitude of the citizens towards the police officers. Principles of the open systems theory demand sound organizational social practices such as transformational leadership efforts, enabling organizational structures, moral principles such as professionalism, and positive organizational politics to influence the perception of external players in the security system. The NPS should strive to create a positive image of the police officers and their responsibilities in the citizens' mind to gain their support and collaboration in delivering security services in the Country (Worrall \& Kjaerulf, 2019).

\subsection{Empirical Review}

Various independent variables including; leadership styles, organizations structure, professionalism and organization politics of the National Police Service as the predicted variable are highlighted.

\subsubsection{Leadership Style and performance}

Muchiri and Hazel (2019) examined how NSE listed commercial banks' performance affected by leadership styles. It adopted a descriptive research design. 88 departmental heads plus their assistants were selected as the target group using stratified random sampling. Primary data gathered by questionnaires was deployed. Multiple regression and correlation analysis was carried out for inferential statistics whereas standard deviation, mean and percentages were used to give descriptive statistics. NSE listed commercial banks' performance and participatory, situational, transactional and transformational leadership had a positive significant association. 
International Journal of Business Management, Entrepreneurship and Innovation, Volume 3, Issue 2, 2021, PP 72-89, ISSN 2707-8027

IBMED

Ngetich and Muchemi (2017) studied the association between lleadership styles and performance of Saccos in Kirinyaga County, Kenya. 303 non-management workers in 4 Kirinyaga County's saccos formed the target population. Stratified random sampling technique was deployed. Information collection was by questionnaires and analysis by multiple regression and descriptive statistics. The study revealed that disclosed that transformational leadership had positive and significant effect on performance, relationship transactional leadership had weak positive significant impact on performance.

Ngaari (2019) study assessed how Kenyan parastatals' organizational performance is influenced by leadership styles: A Kenya power and lighting company headquarter case study. Target population comprised the senior management, middle-level management, and support staff, which comprised of 112 workers and 34 sample size, which was $30 \%$ of the population. Stratified random sampling was adopted in making sure all strata in the research participated in the survey. Descriptive research design was adopted. Information was obtained using self-administered questionnaires and analyzed using qualitative and quantitative data analysis techniques. It was ascertained that Kenyan Parastatals' organizational performance is influenced by democratic, facilitative and transactional leadership styles.

\subsubsection{Organizational structure and performance}

Nene and Pillay (2019) investigated organizational performance is impacted by organizational structure. Inferential and descriptive statistics were used in data analysis. Results indicated the inference between the study' actual aim and the elements and there was evidence of ineffectiveness of organizational structure. The structure's ineffectiveness was seen to be a contributing factor to the respondent's low levels of job satisfaction. Mon (2019) study examined how organizational structure affected manufacturing industry's company performance. Collection of data was done using a questionnaire. The findings indicated that firm performance is significantly affected by technology and formalization and positively and not significantly affected by the organizational structure for complexity and nature of hierarchical variables. Ogbo, Chibueze, Christopher and Anthony (2015) studied how selected Nigerian Technical and Service Firms' organizational performance is impacted by structure. Survey approach was deployed in undertaking the research. Geographically, it was based in Etisalat, Enugu Regional Office and Innoson Nigeria Ltd. Primary and secondary data were utilized. It was clear that in Nigerian Technical and Service Firms, better and more informed decision making was enhanced by decentralization.

\subsubsection{Professionalism and Performance}

Khayatmoghadam (2020) explored how organizational performance is affected by Professional ethics. Correlation approach and descriptive-survey method were applied. The study population Mashhad Municipality's 5000 employees. Using stratified random sampling, a sample size of 357 workers was selected based on Morgan's table. Data gathering was by a questionnaire. Structural model method using LISREL and nonlinear regression test using SPSS were used in data analysis. Based on the findings, organizational performance and professional ethics associated significantly and positively.

Rulandari (2017) investigated how professionalism impacts organizational performance at the social affairs' office in east Jakarta administrative city. Of the 156 staff (study population), 50 participants were sampled and quantitative descriptive approach was deployed. A questionnaire was used as the data collection instrument. The study showed that at the social affairs' office in 
International Journal of Business Management, Entrepreneurship and Innovation, Volume 3, Issue 2, 2021, PP 72-89, ISSN 2707-8027

\section{IBMED}

east Jakarta administrative city, organizational performance was influenced positively by professionalism and supervision both simultaneously and partial building causality relation mechanism.

Ezeanyim and Ezeanolue (2021) study explored the influence of pprofessionalism on oorganizational performance in manufacturing firms in South-East, Nigeria. It adopted descriptive research design. The study group was 4871 (employees of selected manufacturing firms SouthEast). Sample size of nine hundred and twenty-seven (936) participants was selected using Borg and Gall formula. Questionnaire was employed as the main instrument of data collection and analyzed using frequency count and percentages in the analysis of research questions while research hypotheses were tested using panel regression analysis. It was found that ethical climate had significant positive effect on organization' performance in South-East Nigeria.

\subsubsection{Organizational politics and performance}

Olorunleke (2015) investigated how organizational performance was affected by organizational politics. Data from 152 employees who were selected through simple random sampling technique was generated using survey research design. In testing the formulated hypothesis, the variables' relationship strength and direction was determined using correlation analysis. The analysis results indicated that organizational politics and organizational goals achievement and harmony achievement among an organization's functional departments related negatively. Hence it was concluded that putting effort to provide a politics free working environment in the organization can enhance organizational performance. Angasisye (2019) examined organizational politics' effects on organization performance: A Case of Diamond Trust Bank (DTB). An inductive research method was employed. The population involved staff members of headquarters, in which the number of personnel was 525 employees. The study used a sample size of 50 participants randomly purposively selected. Data was gathered by questionnaires and interview methods. The findings disclosed that organization politics and performance strongly associated. The findings show that the performance of the organization is highly influenced by the practice of politics in the organization. Okeke and Mbah (2019) study examined the influence of organizational politics on employee performance: A Study of Selected Anambra State, Nigeria's Tertiary Institutions. Survey research design was implemented. The study population was 5403. Multiple regression analysis method was employed in testing the hypotheses. This investigation discovered that there is a positive association between cultural animosity and organizational performance in tertiary institutions under study. Religious diversity, Pay and promotion and employee performance in tertiary institutions under study positively associated.

\subsection{Conceptual Framework}

The interaction between the independent variables, organizational social practices, and dependent variables, police performance was summarized diagrammatically to provide the conceptual framework as shown in figure 1. 
International Journal of Business Management, Entrepreneurship and Innovation, Volume 3, Issue 2, 2021, PP 72-89, ISSN 2707-8027

E-

\section{Independent Variables}

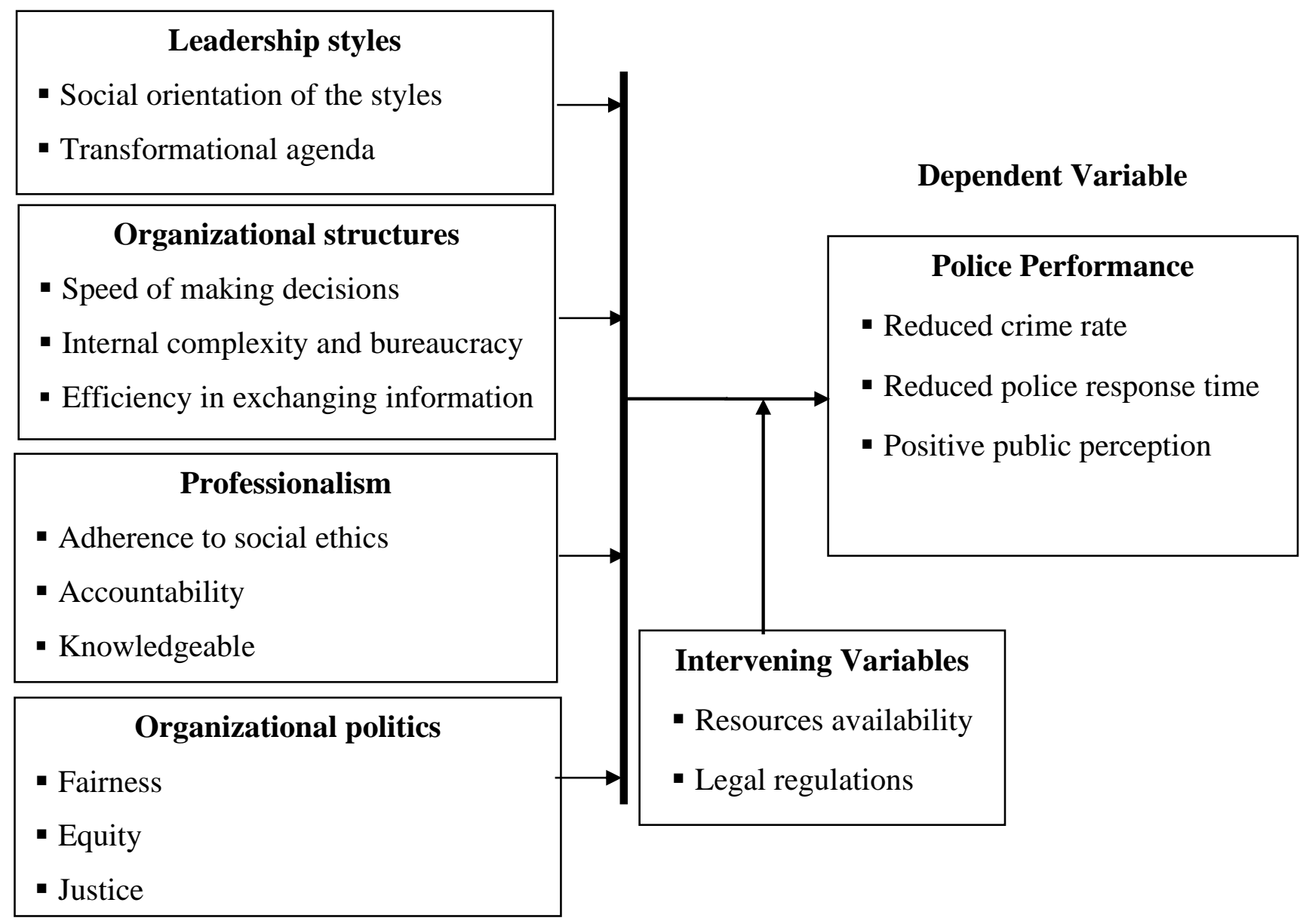

Figure 1: Conceptual Framework

Source: Researcher (2021)

\subsection{0 Research Methodology}

The researcher employed descriptive research design. Mugenda, and Mugenda (2003) defined descriptive research design as one focusing on establishing the association between variables of the frequency with which a phenomenon is occurring. The design was suitable given that the research was aimed at establishing whether the variables had any effect on performance in the National Police Service Central Division Nairobi. The study's target population was 750 police officers at the constable, corporal, and senior sergeant levels at the NPS in this order; senior sergeants 100, corporals 150 and 500 for constables which was carried out at Central Police Division in Nairobi County. A sample of participants was obtained from the officers at Central Police Division in Nairobi Kenya. Purposive sampling method was used to identify study respondents. The said sampling method was preferred by the researcher since it provided for selection of specific group of respondents with adequate knowledge of the study topic. As recommended by Kothari (2004), members of the population who are likely to be less informed about the topic were intentionally excluded. A sample size of 150 participants which is $20 \%$ of the targeted population was computed in line with Saunders (2009) which recommended a $10 \%$ to $30 \%$ sample size in a social science research. 
International Journal of Business Management, Entrepreneurship and Innovation, Volume 3, Issue 2, 2021, PP 72-89, ISSN 2707-8027

IBMED

The researcher used both primary and secondary data in achieving the study objective. Self administered questionnaires, helped obtain primary data whereas secondary data was collected from published reports and other documents using desk search techniques. The questionnaires contain four sections; one that collects social practices and the other the factors affecting NPS performance. The questions were based on how variables measured at both intervals and nominals. A 5-point Likert scale in which 1 is "consistent" and 5 is "consistent" is used to measure the consent of the respondents to the concepts being investigated (Likert, 2003). Additionally, the researcher was able to gather qualitative information through the semi-structured questions within the questionnaire. Structure questionnaires was deployed to facilitate collection of primary data in accordance with the pre-established research objectives. The questionnaire bear structured and unstructured questions to ensure in-depth gathering of insights on the study variables. The structured questions followed the Likert scale for participants' measurement on the options of various performance aspects. A questionnaire was self-administered to each participant and picked after two weeks for coding and analysis of the collected data. To ensure completeness and consistency before the answers were processed, the completed questionnaires were sorted. Analysis of quantitative data was done using SPSS in which descriptive and inferential statistics like standard deviations, means, percentages, frequencies, correlations, and regression coefficients.

\subsection{Data Analysis Results}

\subsection{Correlation analysis}

The correlation analysis aimed at measuring the variables' relation by holding all other variables constant. Hence, every partial correlation coefficient measures how the dependent variable is affected by its independent variable as presented in table 1 below.

Table 1: Pearson Correlation Coefficients

\begin{tabular}{llllll}
\hline & $\begin{array}{l}\text { Performance } \\
\text { of NPS }\end{array}$ & $\begin{array}{l}\text { Organization } \\
\text { Politics }\end{array}$ & $\begin{array}{l}\text { Leadershi } \\
\text { p Styles }\end{array}$ & $\begin{array}{l}\text { Organizatio } \\
\mathrm{n} \text { Structure }\end{array}$ & $\begin{array}{l}\text { Professio } \\
\text { nalism }\end{array}$ \\
\hline Performance of NPS & 1.000 & & & \\
Organization Politics & -.536 & 1.000 & & \\
Leadership Styles & .752 & .118 & 1.000 & & \\
Organization Structure & .467 & .128 & .247 & 1.000 & \\
Professionalism & .307 & .254 & .254 & .380 & 1.000 \\
\hline
\end{tabular}

Source: Survey Data (2021)

The four independent variables are said to be correlated if their coefficient of correlations is greater than 0.5. In such a situation one of the variables must be dropped from the analysis. As illustrated above, none of the predictor variables had correlation coefficient between themselves more than 0.5 thus all were included in the model. Further, the matrix indicated high correlation between the dependent and predictor variables which were; organization politics, leadership styles, organization structure, and professionalism. The first column in table 4.5 shows the direction and magnitude of correlation between NPS performance and each of the four organizational social practices. The analysis indicates positive correlations between performance and all the organizational social practices, except organization politics which has a negative correlation. It is 
International Journal of Business Management, Entrepreneurship and Innovation, Volume 3, Issue 2, 2021, PP 72-89, ISSN 2707-8027

E-

important to note that leadership style has the strongest correlation (0.752), followed by organization politics at -0.536 , organization structure at 0.467 , and professionalism at 0.307 . These statistics suggest substantial relationships between organizational social practices and performance of NPS. However, there is need for further interrogation of the relationship to establish the relationship significance as presented in the following regression analysis section.

\subsection{Regression analysis}

The study applied multivariate regression analysis in order in establishing the relative importance of the four variables with respect to the Performance of NPS. The regression model was tested to establish its suitability in explaining the relationship between the four organizational social practices and performance of NPS. Table 4.6 provide a summary of the model;

Table 2: Model Summary

\begin{tabular}{|c|c|c|c|c|c|c|c|c|c|}
\hline \multirow[b]{2}{*}{ Model } & \multirow[b]{2}{*}{$\mathrm{R}$} & \multirow[b]{2}{*}{$\begin{array}{l}\mathrm{R} \\
\text { Square }\end{array}$} & \multirow[b]{2}{*}{$\begin{array}{l}\text { Adjusted } \\
\text { R Square }\end{array}$} & \multirow{2}{*}{$\begin{array}{l}\text { Std. Error } \\
\text { of the } \\
\text { Estimate }\end{array}$} & \multicolumn{5}{|c|}{ Change Statistics } \\
\hline & & & & & $\begin{array}{l}\text { R Square } \\
\text { Change }\end{array}$ & $\begin{array}{l}\mathrm{F} \\
\text { Change }\end{array}$ & df1 & df2 & $\begin{array}{l}\text { Sig. F } \\
\text { Change }\end{array}$ \\
\hline 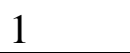 & $.918(a)$ & .843 & .805 & .51038 & .843 & 1.242 & 2 & 140 & .000 \\
\hline
\end{tabular}

*Dependent Variable: performance of NPS

\section{Source: Survey Data, 2021}

Table 2 analysis shows that the determination coefficient (the percentage variation in the performance of NPS being explained by the changes in organizational social practices that was represented by the $\mathrm{R}^{2}=0.843 ; \mathrm{P}=0.000$. That is, Organization Structure, Organization Politics, Professionalism and Leadership Styles have 84.3 percent influence performance. Therefore, model was adequately suitable since it could explain over $80 \%$ percent of the variation in NPS and only 15.7 of the variations could be explained by other factors outside the organizational social practices included in the current study. The significance level $(\mathrm{p}=0.00)$ confirms that there existed a notable association between the predictor variables (organizational social practices) and dependent variable (performance of NPS). Hence, the null hypothesis that there is no relationship between organizational social practices and NPS performance should be rejected.

Coefficients of the predictor variables (leadership style, organization structure, organization politics, and professionalism) were computed to determine the individual effect of the variables on NPS performance as shown in table 3 below.

Table 3: Coefficients of Regression Analysis

\begin{tabular}{|c|c|c|c|c|c|}
\hline & \multicolumn{2}{|c|}{ Unstandardized Coefficients } & \multirow{2}{*}{$\begin{array}{c}\text { Standardized Coefficients } \\
\text { Beta } \\
\end{array}$} & \multirow[t]{2}{*}{$\mathrm{t}$} & \multirow[t]{2}{*}{ Sig. } \\
\hline & $\mathrm{B}$ & Std. Error & & & \\
\hline (Constant) & .260 & .460 & & 0.565 & .231 \\
\hline Leadership Styles & .170 & .045 & .300 & 3.778 & .000 \\
\hline Organization Structure & .051 & .023 & .113 & 2.217 & .002 \\
\hline Organization Politics & -.131 & .048 & -.254 & 2.729 & .001 \\
\hline
\end{tabular}


International Journal of Business Management, Entrepreneurship and Innovation, Volume 3, Issue 2, 2021, PP 72-89, ISSN 2707-8027

IBNED

\begin{tabular}{llllll} 
Professionalism & .048 & .022 & .093 & 2.182 & .000 \\
\hline
\end{tabular}

Dependent Variable: performance of NPS

\section{Source: Survey Data, 2021}

The regression analysis in table 4.7 indicates that all the four independent variables had statistically significant relationships with NPS performance since none of them had a p-value greater than 0.05. The values in Beta column provide the influence factor of each variable and formulated in the previously formulated model as; $\mathrm{Y}=0.260+0.170 \mathrm{X}_{1}+0.51 \mathrm{X}_{2}-0.131 \mathrm{X}_{3}+0.048 \mathrm{X}_{4}$. Since $\mathrm{Y}$ denotes the NPS performance, the model suggests that the performance of NPS would be at 0.260 units if Organization Structure, Organization Politics, Professionalism and Leadership Styles are all rated as zero. Otherwise, leadership style was established to have the greatest influence $(0.300)$ on NPS performance. This implies that NPS is likely to improve its performance by 0.300 units if it improves its style of leadership by one unit. Organization politics had the second but negative impact (-0.254) on NPS performance. A unit increase in internal politics of NPS is likely to decrease its performance by 0.254 units and the opposite is true for the two variables. Organization structure and professionalism had individual impacts of 0.113 and 0.093 units respectively. Therefore, professionalism seems to have the least influence on the performance of police officers. This might be explained by the indifferent nature of police service and means of measuring performance of police officers. Some of the common ways of measuring performance of police service include number of arrests and crime incidents. Such measures fails to incorporate elements professionalism in their evaluation of the police officers' performance.

\subsection{Conclusions and Recommendations}

\subsection{Conclusion}

The study concludes that the main belief or attitude influencing leadership style is the perceived manager versus subordinates' role. Superiors' persistent thinking pattern with respect to individual groups or their subordinates is typically represented by leadership styles. A leader takes up the responsibility of coaching workers depending on the leadership type. The way workers perceive their manager is affected by factors like experience, skills and knowledge and education level. The study concludes that effective decision making is improved by decentralization, narrow control span and efficiency relate positively, task routine positively and negatively affect productivity. Operational efficiency is improved by organizational structure through provision of clarity to workers at all company levels. Tighter managerial control will result from more centralization, formalization the extent to go which jobs are standardized and governed by procedures and greater and formalization is probable to improve individual operations' efficiency.

The study concludes that a respectful culture is fostered by professionalism, which ensure proper handling of conflicts. Boundaries are clearly understood and minor issues solve efficiently and respectfully by professional employees. A professional environment establishes respect to fellow colleagues and clients and gives help in limiting individual conversations that are inappropriate or disrespectful. When an employee continues to behave professionally despite the other party making inappropriate comments, it shows the respect level for a business partnership or client. The study concludes that workers are motivated with the hope that there won't be hampering of their interest due to existence of organizational politics. Employee's indiscipline may be resisted by the organizational politics' help. Through the existence of political influence, employees may be 
International Journal of Business Management, Entrepreneurship and Innovation, Volume 3, Issue 2, 2021, PP 72-89, ISSN 2707-8027

\section{IBMED}

convinced about the organizational goals and plans. Employees' aspiration and hopes maybe given recognition and dignity by management or employer or management

\subsection{Recommendations}

The study recommends that transactional and transformative leadership be embraced by national police service to assist in tapping the workers' potential, they should be involved in making decisions and new idea be welcomed into the system for positive contribution to the entities' exponential performance. Leaders should understand how workers perceive the style of leadership so that the institution can realize its objectives. Therefore, employees should be equally treated thus not all styles can fit all employee levels. The study recommends that national police service should adopt an efficient, simple and universally accepted organizational structure. In decision making process improvement, more decentralized forms of structures be adopted by the organization, that employees be empowered to be more innovative in undertaking their duties, whether routine or not and that in organizing employees for carrying out task, both task routine and variety should be combined by managers so as to reap the advantages of task assignment both systems.

The study recommends that employees at national police service should exercise workplace expectations and rules by following all workplace rules, completing all projects and tasks and understanding what is expected of them. Learn to be responsible for their words, actions and ultimately their work performance. Ask for help if someone is not sure how to handle a situation and always follow company policy and report anything that does not follow policy. The study recommends delegation of duties depending on employees' academic achievements, specialization and interests. In reducing politics, at all levels transparency should be maintained. Employees to know the organization's objectives and goals and put effort in achieving them. For each individual, organization policies should be same. Teamwork should be encouraged and promoted to enable employees coming closer and developing a liking for one another.

\section{References}

Alexander, L. D. (2003). Strategy practices and performance: nature of the problem, International Review of Strategic Management Journal, Sage Publications, London.

Angasisye, M. (2019). The Effects of Organizational Politics on Organization Performance, A Case of Diamond Trust Bank (DTB) (Doctoral dissertation, Mzumbe University).

Balogun, J., Johnson, G. (2004). Organizational restructuring and middle manager sense making, Academy of Management Journal, London.

Barney, J. B. (2003). Firm Resources and Competitive Advantage, Journal of Management, 17(1) 99-140

Bartlett, C.A., Goshal, S. (2006). Release the entrepreneurial hostages from your corporate hierarchy, Strategy Leadership Journal, Vol. 24 McGraw-Hill: New York

Beer, M, and Eisenstat, R (2000). The silent killers of strategy practices and performance and learning,

Bennett, W., Lance, C., \& Woehr, D. (2014). Performance measurement: Current perspectives and future challenges. Oxford: Psychology Press

Botha, A., \& Abdile, M. (2020). Experiences in the Kenyan Criminal Justice System and Violent Extremism. 
International Journal of Business Management, Entrepreneurship and Innovation, Volume 3, Issue 2, 2021, PP 72-89, ISSN 2707-8027

E-

Brehm, B., Smith, R., Wall, A., \& Warren, N. S. (2016). An interdisciplinary approach to introducing professionalism. American Journal of Pharmaceutical Education, 70(4), 23 36

Brussels: European Community Programme for Employment and Social Solidarity.

Corsaro, N., Frank, J., \& Ozer, M. (2015). Perceptions of police practice, cynicism of police performance, and persistent neighborhood violence: An intersecting relationship. Journal of Criminal Justice, 43(1), 1-11.

Duijn, P. A., \& Klerks, P. P. (2014). Social network analysis applied to criminal networks: recent developments in Dutch law enforcement. In Networks and network analysis for defence and security (pp. 121-159). Springer, Cham.

Ezeanyim, E. E., \& Ezeanolue, E. T. (2021). Professionalism and Organizational Performance in Manufacturing Firms in South-East, Nigeria. International Journal of Business \& Law Research, 9(3), 1-14

Ferris, G. R., \& Kacmar, K. M. (2017). Perception of organizational politics. Journal of Management, 18(1), 93 - 116

Fubara, S. (2020). Social Awareness and Organizational Innovativeness of Manufacturing Firms in Rivers State, Nigeria. International Journal of Business \& Law Research, 8(1), 63 - 73

Fu-Jin, W. Shieh, C., \& Tang, M. (2016). Effect of leadership style on organizational performance as viewed from human resources management strategy. African journal of business management, 4(18), 3924 - 3936.

Garcia, N. H., \& Acosta, A. S. (2020). What Made You Who You Are? Universal Life Lessons on Proversified Leadership, a Phenomenology. American International Journal of Contemporary Research, 10(2).

Gull, S., \& Zaidi, A. A. (2019). Impact of Organizational Politics on Employees' Job Satisfaction in the Health Sector of Lahore Pakistan. Interdisciplinary Journal of Contemporary Research in Business, 4(2): 156-170.

Hameed, S. K. (2019). Corporate social responsibility (CSR) theory and practice in Pakistan (Swedish University of Agricultural Sciences)

Harvey, D. (2005). The new imperialism. OUP Oxford.

Hope Sr, K. R. (2015). In pursuit of democratic policing: An analytical review and assessment of police reforms in Kenya. International Journal of Police Science \& Management, 17(2), 9197.

Jeremy, M, Melinde, C., \& Ciller, V. (2018). Perceived leadership style and employee participation in a manufacturing company in the democratic republic of Congo. African journal of business management, 6(15), 5389-5398

Joseph, K. K., Christine, K. A., \& Joash, M. (2016). Assessment on the influence of top leadership on service delivery in the Kenya police service in Kitui County.

Karaite, E.K. (2011). "Management of Strategic Change at Kenya Police Service”. (Unpublished Master's Research Project)

Kenya Constitution. (2010). The Constitution of Kenya 2010. National Council for Law Reporting. www.kenyalaw.org

Kenya Police Force (2003). Kenya Police Force Strategic Plan 2003-2008; Nairobi: Government Press

Khayatmoghadam, S. (2020). The Effect of Professional Ethics on the Organizational performance. International Journal of Ethics \& Society (IJES), 2(1), 25 - 33 
International Journal of Business Management, Entrepreneurship and Innovation, Volume 3, Issue 2, 2021, PP 72-89, ISSN 2707-8027

\section{BMED}

Komperda, R., Pentecost, T. C., \& Barbera, J. (2018). Moving beyond alpha: A primer on alternative sources of single-administration reliability evidence for quantitative chemistry education research. Journal of Chemical Education, 95(9), 1477-1491.

Kothari, C. R. (2004). Research methodology: Methods and techniques. New Age International.

Kral, P., \& Kralova, V. (2016). Approaches to changing organizational structure: The effect of drivers and communication. Journal of Business Research, 69(11), 5169-5174.

Kumbargeri, A., \& Sinha, P. K. (2017). The influence of social practices on consumer behaviour: Arguing for its greater incorporation in consumer research. ResearchGate, November.

Leggett T (2009). Performance measurement for the South African Police Service: Setting for service delivery. Transformation: Critical Perspective on Southern Africa, 49(1): 55-58.

Likert, R. (2003). A technique for the measurement of attitudes. Archives of Psychology. New York: Columbia University Press.

Lobo C 2008. Institutional and Organizational Analysis for Pro-Poor Change: Meeting IFAD's Millennium Challenge. Rome, Italy: International Fund for Agricultural Development. From<http://www. ifad.org/English/institutions/sourcebook.pdf> (Retrieved14 February 2015).

Luhangala, H. M., \& Anyieni, A. (2019). Strategy implementation on organization performance: A case of public secondary schools Nyamira County, Kenya. International Academic Journal of Human Resource and Business Administration, 3(5), 394-410

Malik, M. S., Ali, H., \& Ishfaq, A. (2018). Corporate social responsibility and organizational performance: Empirical evidence from banking sector. Pakistan Journal of Commerce and Social Sciences (PJCSS), 9(1), 241-247.

Marginson, D.E.W. (2002). 'Management control systems and their effects on strategy formation at middle management levels: evidence from a UK organization', Strategic Management Journal, Vol. 23 pp.1019

Martin, R. L. (2010). The Execution Trap: Drawing a line between strategy and execution almost guarantees failure. Harvard Business Review.

Martinez-Conesa, I., Soto-Acosta, P., \& Palacios-Manzano, M. (2017). Organizational social practices and its effect on innovation and firm performance: An empirical research in SMEs. Journal of cleaner production, 142, 2374-2383

McClean, E., \& Collins, C. J. (2019). Expanding the concept of fit in strategic human resource management: An examination of the relationship between human resource practices and charismatic leadership on organizational outcomes. Human Resource Management, 58(2), $187-202$.

Miller, D. (2002), 'Successful change leaders: what makes them? What do they do that is different?' Journal of Change Management, Vol. 2 No.4, pp.359-68

Miniace, J.N., Falter, E. (2006). Leadership Styles: a key factor in strategy practices and performance. Planning Review, Vol. 24 pp.26-30.

Mohagheghi, S., \& Raji, N. (2014). Dynamic demand response: A solution for improved energy efficiency for industrial customers. IEEE Industry Applications Magazine, 21(2), 54-62.

Montgomery, C. (2004). "Corporate diversification". Journal of Economic Perspectives, 8, pp.163-178.

Muchiri, K. J., \& Hazel, G. (2019). Effects of leadership styles on organizational performance of listed commercial banks in the Nairobi securities exchange. International Journal of Business Management and Finance, 2(1), 45 - 59 
International Journal of Business Management, Entrepreneurship and Innovation, Volume 3, Issue 2, 2021, PP 72-89, ISSN 2707-8027

IBNED

Mugenda, O. M. and Mugenda, A. G. (2003). Research Methods, Quantitative \& Qualitative Approaches. Nairobi, Acts Press.

Naeem, M. A., \& Welford, R. (2019). A comparative study of corporate social responsibility in Bangladesh and Pakistan. Corporate Social Responsibility and Environmental Management, 16(2), 108-122.

Nasieku, T., Togun, O. R., \& Olubunmi, E. M. (2014). Organizational social practices and organizational performance: A theoretical review. International Journal of Humanities Social Sciences and Education, 1(12), 106-114.

Newhan Gareth 2006. Towards a New Approach: Monitoring Metropolitan Police Departments by the Gauteng Department of Community Safety. Research Report. Centre for the Study of Violence and Reconciliation, July 2006. Johannesburg, South Africa.

Ngaari, M. B. (2019). Influence Of Leadership Styles On Organizational Performance Of Parastatals In Kenya: A Case Study Of Kenya Power And Lighting Company Headquarter (Doctoral dissertation, MUA).

Ngechu. M. (2004). Understanding the research process and methods. An introduction to research methods. Nairobi, Acts Press

Ngetich, E. K., \& Muchemi, A. W. (2017). Leadership Styles and Performance of Saccos in Kirinyaga County, Kenya (Doctoral dissertation, Kenyatta University).

Nicolini, D. (2012). Practice theory, work, and organization: An introduction. OUP Oxford.

Njoroge, C. N., \& Yazdanifard, R. (2014). The impact of social and emotional intelligence on employee motivation in a multigenerational workplace. Global Journal of Management and Business Research.

Njuguna, E., Ndung'u, J., \& Achilles, K. (2015). Institutionalizing police reforms in Kenya: Lessons from 2012-2015. SAFEWORLD preventing violent conflict, building safer lives.

Nunn, A. (2012). Performance Management on Public Employment Services. Analytical Paper.

Okeke, G. N., \& Mbah, A. P. S. I. (2019). Organisational politics and employee performance: A Study of Selected Tertiary Institutions in Anambra State, Nigeria. Global Journal of Education, Humanities \& Management Sciences, 1(2), 5 - 14

Olorunleke, G. K. (2015). Effect of organizational politics on organizational performance. International Journal of Academic Research in Economics and Management Sciences, 4(3), 59-70.

Petrović, N., Albahari, N., Kajganović, J., \& Baćanović, N. (2016). Collection of policy papers on security policy from the perspective of young leaders. ISAC Fond. www.isac-fund.org

Petrović, N., Albahari, N., Kajganović, J., \& Baćanović, N. (2016). Collection of policy papers on security policy from the perspective of young leaders. ISAC Fond. www.isac-fund.org

Pfeffer, J., \& Salancik, G. R. (2003). The external control of organizations: A resource dependence perspective. Stanford University Press.

Porter, M.E. (1990). The Competitive Advantage of Nations. London: Macmillan.

Porter, M.E. (1996). Competitive Advantage: Creating and Sustaining Superior Performance, with a new introduction. New York: Free Press.

Porter, M.E. (1998b). Clusters and the new economics of competition ", Harvard Business Review, 76(6): 77-90.

Raijin, J. (2012). Employee Assistance Programme in the South African Police Service: A Case Study of Moroka Police Station. M Tech Dissertation, Unpublished. Johannesburg: University of Johannesburg 
International Journal of Business Management, Entrepreneurship and Innovation, Volume 3, Issue 2, 2021, PP 72-89, ISSN 2707-8027

E-

Randeree, K. and Al Youha, H. (2009), "Strategic management of performance: an examination of public sector organizations in the United Arab Emirates", International Journal of Knowledge, Culture and Change Management, Vol. 9 No. 4, pp. 123-134.

Rapa, A. and Kauffman, D. (2005). Strategy practices and performance - an Insurmountable Obstacle?Handbook of Business Strategy. Sloan Management Review Journal, 6(1), pp 141146, Vol. 41 No.4, pp.29-40.

Rulandari, N. (2017). The effect of professionalism on organizational performance at the office of social affairs in east Jakarta administrative city. International Journal of Humanities and Social Science, 7(2), 184-192.

Shane, J. M. (2010). Organizational stressors and police performance. Journal of Criminal Justice, 38(4), 807-818. doi:10.1016/j.jcrimjus.2010.05.008

Smith, C., Fallon, B., Fluke, J. D., Mishna, F., \& Decker Pierce, B. (2019). Organizational Structure and the Ongoing Service Decision: The Influence of Role Specialization and Service Integration. Human Service Organizations: Management, Leadership \& Governance, 43(5), 375-391.

Smith, H. A., \& McKeen, J. D. (2015). Developments in practice XI: Developing IT professionalism. Communications of the Association for Information Systems, 12(1), 20 35

Spanos, Yiannis and Lioukas, Spyros, (2001) "An examination into the causal logic of rent generation: Contrasting Porter's competitive strategy framework and the resource-based perspective”, Strategic Management Journal, Vol. 22, No. 10, 907-934.

Sparrow, M. K. (2015). Measuring performance in a modern police organization. Psychosociological Issues in Human Resource Management, 3(2), 17-52.

Stone, C., \& Travis, J. (2013). Toward a new professionalism in policing. Australasian Policing, 5(1), 23-32.

UNODC. (2011). Handbook on police accountability, oversight and integrity. In Criminal Justice Handbook Series. www.unodc.org

Wanjiku, E. (2019). Impact of Corporate Social Responsibility on Organizational Performance of Security Firms in Kenya: A Case of Group 4 Security Company (Doctoral dissertation, United States International University-Africa).

Waweru, S. W., \& Maina, S. (2019). Corporate restructuring and organization performance of national police service in Kenya. International Academic Journal of Human Resource and Business Administration, 3(6), 55-70.

Welch, D., \& Yates, L. (2018). The practices of collective action: Practice theory, sustainability transitions and social change. Journal for the Theory of Social Behaviour, 48(3), 288-305.

Wernerfelt, B., (2004). A Resource Based View of the Firm, Journal of Economics Management Strategy, Vol. 13, pp. 171-180.

Worrall, R., \& Kjaerulf, F. (2019). Transforming minds, people and places: Leadership coalition building as catalyst for intersectoral collaborative in urban violence prevention. Aggression and violent behavior, 47, 282-292.

This is an open-access article published and distributed under the terms and conditions of (c) (†) \&)

the Creative Commons Attribution 4.0 International License of United States unless otherwise stated. Access, citation and distribution of this article is allowed with full recognition of the authors and the source. Copyright, content ownership and liability for content herein remain with the authors. 